\title{
The Influence of Service Quality, Pricing, and Digital Marketing on IndiHome Fiber Costumers Loyalty
}

\author{
Anastasia Tobing ${ }^{1 *}$, Ernes Simorangkir ${ }^{2}$, Misdianto Situmorang $^{3}$, Purnama Yanti \\ Purba $^{*}$
}

1,2,3,4 Fakultas Ekonomi dan Bisnis, Universitas Prima Indonesia, Medan, Indonesia

\section{ART ICLE IN F O}

Article history:

Received April 19, 2021

Revised April 23, 2021

Accepted May 05, 2021

Available online May 25, 2021

Keywords:

service quality, pricing

marketing, loyalty

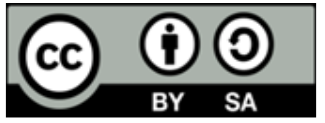

This is an open access article under the CC BY-SA license.

Copyright (c) 2021 by Author. Published by Universitas Pendidikan Ganesha.

\begin{abstract}
A B S T R A C T
Customer loyalty can be influenced by several factors, including service quality, pricing, and digital marketing. This study analyzes the effect of service quality, pricing, and digital marketing on IndiHome Fiber customer loyalty. This research is a descriptive study using a quantitative approach. The population in this study amounted to 16,453 people who are consumers of IndiHome Fiber. Sampling was done by purposive sampling to obtain a sample of 99 people. Data was collected by distributing questionnaires to each sample. The data collected analyzed using multiple linear regression analysis techniques. Analysis prerequisite tests previously preceded it in normality test, multicollinearity test, and heteroscedasticity test. The results of data analysis showed that t-count $(3.129)>\mathrm{t}$-table $(1.98525)$ and -score $(0.002)<(0.05)$, Pricing has a positive and significant score on customer loyalty. It is known that t-count (6.434) > t-table (1.98525) and -score $(0.000)<(0.05)$, Digital Marketing has a positive and significant score on customer loyalty. It is known that $\mathrm{t}$-count $(3.720)>\mathrm{t}$-table $(1.98525)$ and -score $(0.000)<(0.05)$, as well as service quality, pricing, and digital marketing, are simultaneously significant positive on customer loyalty. It is known that F-count (93.612) > F-table (2.70) and -score $(0.000)<(0.05)$. Based on these results, it can be concluded that, partially and simultaneously, service quality, pricing, and digital marketing have a positive and significant influence on IndiHome Fiber customer loyalty.
\end{abstract}

\section{INTRODUCTION}

In today's globalization, almost all human activities pay attention to the development of information technology (Muayyad \& Gawi, 2017; Wood, 2009). Due to advances in communication and information technology, relations between countries, organizations, and individuals, such as there are no intermediaries. In addition, people know more about science as knowledge where information holds an important and real task in life in today's era. So people must be more aware of technology to keep up with the current developments (Khan et al., 2016; Thomas, 2016). Along with the development of technology, the dynamics of economic competition are quite tight. This competition occurs in various business sectors, one of which is in the telecommunications business. An effort is needed to maintain customer trust and loyalty to the products/services offered by a company to support the company's existence in the face of competition (Dasuki, 2017; Wijayanto, 2013). Loyalty is a measure of the customer relationship to a product or service. This measure can describe whether or not customers may switch to other brands (Chrisandi, 2014; Winata \& Andjarwati, 2018). The advantage and the existence of customer loyalty is the reduced influence of attacks and competitors from similar companies, not only competition in terms of perception (Wiranata \& Yuldinawati, 2014). Indicators of customer loyalty are the frequency of using services, recommending to others, not being interested in using the services of other companies, and being loyal to the brand (Hidayat \& Firdaus, 2014; Wiranata \& Yuldinawati, 2014).

PT Telekomunikasi Witel Medan, in carrying out its product marketing activities, still does not maximize digital marketing because it still relies on manual marketing strategies, even though in this day and age, most of everything is online. In addition, PT Telekomunikasi Witel Medan also really needs to pay attention to the quality of service they provide to customers and prospective customers. In addition to adding new customers, they also have to keep old customers continue to subscribe to Indihome Fiber. Suppose some customers report that there is a disturbance or a problem occurs. In that case, PT 
Telekomunikasi Witel Medan must immediately process and not delay so that a customer is satisfied with the service. In addition to digital marketing and service quality, pricing also affects a customer regarding customer loyalty. A customer will test prices unlimitedly by comparing several standard prices for the same product in different places to consider loyalty. Products and prices are appropriate then a consumer will be interested in buying and maintaining the product he has purchased. In addition, a consumer will repurchase at the same place with the same product if he is satisfied with the product (Solihin, 2020; Supariyani \& Hesty, 2014). Several previous studies have examined the factors that influence customer loyalty. First, the study results show that service quality positively impacts customer loyalty (Pakurár et al., 2019; Santosa, 2019). Furthermore, the pricing variable was also found to positively and significantly affect customer loyalty (Aspizain, 2014; Hidayat \& Firdaus, 2014). In addition, digital marketing variables can also influence customer loyalty (Ayuni et al., 2019; Kotler et al., 2017). This study also encourages researchers to research Telkom customer loyalty in the city of Medan in terms of its relationship with service quality factors, pricing, and digital marketing. The purpose of this study is to determine the effect of Service Quality, Pricing, and Digital Marketing on IndiHome Customer Loyalty of PT Telekomunikasi Indonesia, Tbk. Witel Medan. Service quality can be interpreted as an effort to fulfill the needs and desires of consumers and the accuracy of their delivery in balancing consumer expectations (Santosa, 2019). Pricing is a measuring tool for the economic system in influencing the production of a product (Hidayat \& Firdaus, 2014). Digital Marketing uses technology to assist marketing activities that aim to increase consumer knowledge by balancing their needs (Thomas, 2016; Wood, 2009).

\section{METHODS}

The method used in this research is the descriptive verification method with an ex post facto approach and survey. The purpose of this study is verification, namely as a study that aims to determine the influence between two or more variables. The research approach used is an ex post facto approach, which is a study that examines events that have occurred by looking back to find out the factors that can cause these events (Sugiyono, 2018). According to the level of explanation, this type of research is quantitative descriptive, where its use is to analyze data by describing or describing the data collected as they are without intending to make generally accepted conclusions or generalizations. The nature of the research used is descriptive explanatory, which aims to examine causality between variables that explain a particular phenomenon (Moleong, 2004). This study analyzes the effect of Service Quality, Pricing, and Digital Marketing on IndiHome Customer Loyalty. The relationship between variables in this study is presented in Figure 1.

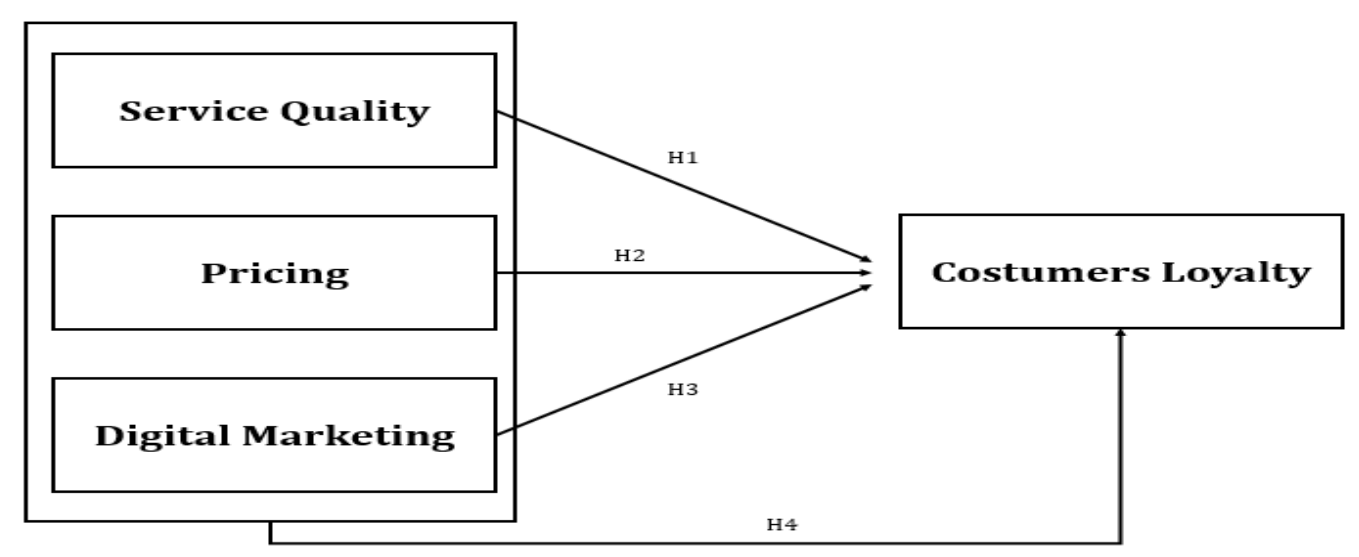

Figure 1. Research Design

The research was conducted at PT Telekomunikasi Indonesia, Tbk. Witel Medan. The time of this research was carried out from September 2020 to May 2021. In this study, the population in this study were IndiHome Fiber users in Medan in January 2019 - December 2019, as many as 16,453 people. Sampling was carried out by purposive sampling with three criteria: the people of Medan who still use IndiHome, people who use it from 2016 to 2019, and researchers including people who are loyal to using IndiHome products and are also capable of answering the questionnaires given later. The number of samples in this study was 99 people. The details of the respondents in this study are presented in Table 1. 
Table 1. Description of Respondents

\begin{tabular}{lcc}
\hline \multicolumn{1}{c}{ Description of Respondents } & Frequency & Percentage (\%) \\
\hline Gender & 55 & 55,6 \\
\hline Man & 44 & 44,4 \\
Woman & & 16,2 \\
Age & 16 & 32,3 \\
20 - 30 years old & 32 & 41,4 \\
31 - 40 years old & 41 & 10,1 \\
41 - 50 years old & 10 & 18,2 \\
$>50$ tahun & & 61,6 \\
\hline Education & 18 & 20,2 \\
\hline D3 & 61 & 23,2 \\
S1 & 20 & 69,7 \\
S2 & & 7,1 \\
\hline Profession & 23 & \\
\hline Polri/TNI/PNS & 69 & 37,4 \\
entrepreneur & 7 & 44,4 \\
Lain-lain & & 18,2 \\
\hline Long Subscription & 37 & \\
\hline < 1 year & 44 & 18 \\
1 - 5 years & & \\
$>$ 5 years & & \\
\hline
\end{tabular}

Data collection in this study used an instrument in the form of a questionnaire. The questionnaires used include consumer perceptions of service quality, pricing, digital marketing, and consumer loyalty. The questionnaire instrument has gone through the stages of testing the validity and reliability. Data collection was also carried out using interview techniques and documentation studies. The data analysis used in this research is multiple linear regression analysis. The prerequisites for the analysis carried out before performing multiple linear regression analysis. It includes normality test, multicollinearity test, and heteroscedasticity test.

\section{RESULTS AND DISCUSSIONS}

\section{Result}

\section{Analysis Prerequisite Test Results}

The results of the analysis prerequisite tests carried out in this study. It includes the normality test of the data distribution, multicollinearity test, and heteroscedasticity test. The results of the prerequisite analysis test are presented as follows.

Table 2. Normality Test Results

\begin{tabular}{llr}
\hline & & Unstandardized Residual \\
\hline N & & $\mathbf{9 9}$ \\
\hline Normal Parameters ${ }^{\text {a,b }}$ & Mean & .0000000 \\
& Std. Deviation & 1.06970124 \\
Most Extreme Differences & Absolute & 0.065 \\
& Positive & 0.062 \\
& Negative & -0.065 \\
\hline Test Statistic & & $\mathbf{0 . 0 6 5}$ \\
\hline Asymp. Sig. (2-tailed) & & $\mathbf{0 . 2 0 0}$ \\
\hline
\end{tabular}

Asymp Score. Sig. (2-tailed) shows 0.200 . Based on these data, it was concluded that there were test results whose results were $0.200>0.05$; and clarify the distribution of research data otherwise normal. The following prerequisite test is the multicollinearity test. The results of the multicollinearity test are presented in Table 3. The results of the multicollinearity test showed a tolerance score $>0.10$ and a VIF score < 10 for research variables of service quality, pricing, digital marketing. It shows no multicollinearity in the regression model so that the data is said to be good and can be used for further testing. The next test carried out is the heteroscedasticity test. The results of these tests can be seen in the scatterplot graph presented in Figure 3. 
Table 3. Multicollinearity Test Results

\begin{tabular}{|c|c|c|c|c|c|c|c|}
\hline \multirow[b]{2}{*}{ Model } & \multicolumn{2}{|c|}{$\begin{array}{l}\text { Unstandardized } \\
\text { Coefficients }\end{array}$} & \multirow{2}{*}{$\begin{array}{c}\begin{array}{c}\text { Standardized } \\
\text { Coefficients }\end{array} \\
\text { Beta }\end{array}$} & \multirow[b]{2}{*}{$\mathbf{T}$} & \multirow[b]{2}{*}{ Sig. } & \multicolumn{2}{|c|}{$\begin{array}{l}\text { Collinearity } \\
\text { Statistics }\end{array}$} \\
\hline & B & Std. Error & & & & Tolerance & VIF \\
\hline 1 (Constant) & 5.381 & 1.091 & & 4.930 & 0.000 & & \\
\hline Service quality & 0.174 & 0.056 & 0.242 & 3.129 & 0.002 & 0.446 & 2.241 \\
\hline Pricing & 0.323 & 0.050 & 0.468 & 6.434 & 0.000 & 0.503 & 1.989 \\
\hline $\begin{array}{l}\text { Digital } \\
\text { Marketing }\end{array}$ & 0.203 & 0.055 & 0.272 & 3.720 & 0.000 & 0.498 & 2.007 \\
\hline
\end{tabular}

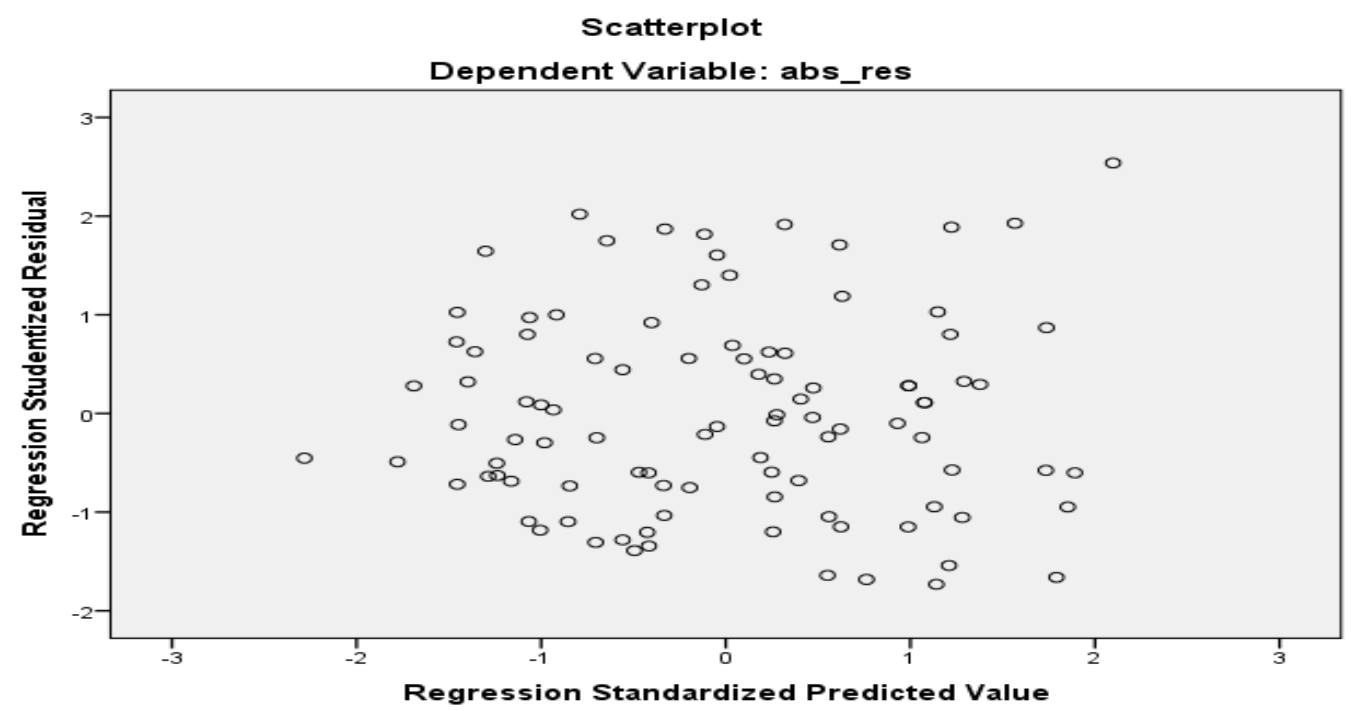

Figure 3. Scatterplot

From the figure, the distribution of points is irregularly above or below the 0 of the $\mathrm{Y}$ axis. Therefore, it is concluded that the research is stated to be independent of heteroscedasticity.

\section{Multiple Linear Regression Analysis}

Table 4. Test Results of Multiple Linear Regression Analysis

\begin{tabular}{|c|c|c|c|c|c|c|}
\hline \multirow[b]{2}{*}{ Model } & & \multicolumn{2}{|c|}{ Unstandardized Coefficients } & Standardized Coefficients & \multirow[b]{2}{*}{$\mathbf{T}$} & \multirow[b]{2}{*}{ Sig. } \\
\hline & & B & Std. Error & Beta & & \\
\hline 1 & (Constant) & 5.381 & 1.091 & & 4.930 & .000 \\
\hline & Service quality & .174 & .056 & .242 & 3.129 & .002 \\
\hline & Pricing & .323 & .050 & .468 & 6.434 & .000 \\
\hline & $\begin{array}{l}\text { Digital } \\
\text { Marketing }\end{array}$ & 203 & .055 & .272 & 3.720 & .000 \\
\hline
\end{tabular}

Based on the results shown in table 4 , an equation can be drawn up for this test, namely:

$$
\mathrm{Y}=5,381+0,174 \mathrm{X1}+0,323 \times 2+0,203 \times 3 e
$$

From the regression equation above, several things can be interpreted, including: The constant score of 5.381 which states that if the independent variable is considered a construct, then the average customer loyalty $(\mathrm{Y})$ is 4.580 ; The service quality variable (X1) on customer loyalty $(\mathrm{Y})$ has a regression coefficient score of 0.174 which means, for every increase in service quality (X1), customer loyalty (Y) will increase by 0.174 with the assumption that the other independent variables of the regression model are permanent; The pricing variable (X2) on customer loyalty $(\mathrm{Y})$ has a regression coefficient score of 0.323 which means, for every increase in pricing (X2), customer loyalty (Y) will increase by 0.323 with the assumption that the other independent variables from the regression model are permanent; The digital marketing variable (X3) on customer loyalty $(\mathrm{Y})$ has a regression coefficient score of 0.203 which means, 
for every increase in digital marketing (X3), customer loyalty (Y) will increase by 0.203 with the assumption that the other independent variables from the regression model are permanent.

\section{Hypothesis testing}

Based on the results of the analysis, it can be seen that the $\mathrm{F}$ table score is 2.70 , so that the point is $\mathrm{F}$ arithmetic $>\mathrm{F}$ table $(93.612>2.70)$. The significant score is $0.000<0.05$. It can be concluded that $\mathrm{H} 0$ is rejected and $\mathrm{H} 4$ is accepted to understand that the variables of service quality, pricing, and digital marketing simultaneously have a positive and significant impact on customer loyalty at PT Telekomunikasi IndiHome Indonesia, Tbk. Witel. The test criteria used are comparing tcount with ttable based on a significant 0.05 with two sides and degrees of freedom $\mathrm{df}(\mathrm{nk})=95$ (is the number of data and is an independent variable) ttable obtained from the statistical table is 1.98525 . Based on the results of the analysis, several results were obtained as follows. First, based on the significance score of the Service Quality variable (X1) is $0.002<0.05$ probability, with a tcount of $3.129>$ ttable 1.98525 , then $\mathrm{H} 0$ is accepted. It shows that the service quality variable has a positive and significant effect on customer loyalty. Second, based on the significance score of the Pricing variable (X2) is $0.000<0.05$ probability, with a tcount of $6.434>1.98525$ ttable, then H0 is accepted. It shows that the variable of pricing has a positive and significant effect on Customer Loyalty. Third, based on the significance score of the Digital Marketing variable (X3) is $0.000<0.05$ probability, with a tcount of $3.720>$ ttable 1.98525 , then $\mathrm{H} 0$ is accepted. It shows that the Digital Marketing variable has a positive and significant effect on Customer Loyalty.The results of the analysis show that the Adjusted $\mathrm{R}^{2}$ number of 0.739 is equal to $73.9 \%$. It can be seen that the customer loyalty variable is manifested by the variables of service quality, pricing, and digital marketing of $73.9 \%$. In comparison, $26.1 \%$ is displayed by other variables that are not observed, such as Trust, Product Quality, etc.

\section{Discussion}

Based on the research results that have been presented, several things can be interpreted as follows. First, the regression analysis results obtained that the regression coefficient of the service quality variable (X1) is positive and a significant score of $0.002<0.05$, indicating that service quality impacts customer loyalty. It is concluded that $\mathrm{H} 1$ is accepted. The hypothesis explains that service quality has a positive impact on customer loyalty. This study is in line with previous research, which found that service quality positively affects customer loyalty and the significance of customer loyalty (Pakurár et al., 2019; Santosa, 2019). Service quality is defined as an effort to fulfill the needs and desires of consumers and the accuracy of their delivery in balancing consumer expectations (Kurniawan, 2016). In research-based on service quality questionnaires, respondents agree more on service quality with complete IndiHome Fiber features and comprehensively shared information. Employees are serious in handling complaints or problems with customers, and employees can resolve problems complaints quickly.

Second, the regression analysis results obtained that the Pricing Variable (X2) regression coefficient was positive and a significant score of $0.000<0.05$, indicating that pricing impacts Customer Loyalty. It is concluded that $\mathrm{H} 2$ is accepted. The hypothesis explains that pricing has a positive effect on customer loyalty. This study is in line with the findings of previous studies, which state that pricing positively affects customer loyalty and the significance of customer loyalty (Aspizain, 2014; Hidayat \& Firdaus, 2014). Pricing is defined as a measuring tool for the economic system in influencing the production of a product (Petricia \& Syahputra, 2015; Sumiati \& Mujanah, 2018). In the research results based on the pricing questionnaire, respondents agree more in pricing that IndiHome Fiber provides many price options. The price of IndiHome Fiber is set according to the facilities offered. Third, the regression analysis shows that the regression coefficient of the Digital Marketing variable (X3) is positive and a significant score of $0.000<0.05$, stating that digital marketing has an impact on Customer Loyalty. It is concluded that $\mathrm{H} 3$ is accepted. The hypothesis explains that digital marketing has a positive effect on customer loyalty. This study is in line with previous research, which concluded that digital marketing positively affects customer loyalty and the significance of customer loyalty (Ayuni et al., 2019; Kotler et al., 2017). Digital Marketing can assist targeted marketing activities in increasing consumer knowledge by balancing their needs (Hardilawati, 2020; Srisusilawati, 2017; Untari \& Fajariana, 2018). Based on digital marketing questionnaires, respondents agree more in digital marketing that IndiHome Fiber advertises on the internet. IndiHome Fiber text ads almost always appear on website pages that customers visit.

Fourth, the regression analysis obtained the regression coefficients for the variables of Service Quality (X1), Pricing (X2), and Digital Marketing (X3) simultaneously with positive scores and a significant score of $0.000<0.05$ knowledge has an impact on Customer Loyalty. It is concluded that $\mathrm{H} 4$ is accepted. The hypothesis explains that service quality, pricing, and digital marketing positively impact customer loyalty. It is in line with previous research, which states that customer loyalty is influenced by several 
factors, including service quality, price, and digital marketing (Hardilawati, 2020; Hidayat \& Firdaus, 2014). Based on the study results, the company should be able to maximize the role of Service Quality, Pricing, and Digital Marketing so that it can have an impact on maximizing customer loyalty, such as for service quality to increase the ability of workers to respond quickly to serve the community, such as being more familiar with customers so that they can take action and more experience in solving problems, as well as conducting online and direct surveys to customers' homes for criticism and input on the quality of service provided by employees; for pricing so that there is a discount in certain months with the aim that more people can use IndiHome Fiber to subscribe, provide additional packages for those who subscribe for more than two years to get an advantage over competing products, and so on; and for digital marketing to increase its network connections again. There are still factors other than Service Quality, Pricing, and Digital Marketing that affect Customer Loyalty. It is necessary to further research other factors where there may be risks to Customer Loyalty, such as Trust, Product Quality, etc. For further researchers who examine the same topic for different types of companies to multiply the research variables, it can be seen more clearly which variables are more dominant in influencing Customer Loyalty. In addition, it is hoped that further researchers can conduct customer loyalty research at Telkom, but in other places such as banks, pawnshops, and restaurants.

\section{CONCLUSION}

Partially and simultaneously, service quality, pricing, and digital marketing have a positive and significant impact on customer loyalty IndiHome Fiber at PT Telekomunikasi Indonesia, Tbk. Witel Medan. Based on these findings, the company should be able to maximize the role of Service Quality, Pricing, and Digital Marketing so that it can have an impact on maximizing Customer Loyalty, such as for service quality to increase the ability of workers to respond quickly to serve the community, such as being more familiar with customers so that they can take action and more experience in solving problems, as well as conducting online and direct surveys to customers' homes for criticism and input on the quality of service provided by employees; for pricing so that there is a discount in certain months with the aim that more people can use IndiHome Fiber to subscribe, provide additional packages for those who subscribe for more than two years to get an advantage over competing products, and so on; and for digital marketing to increase its network connections again.

\section{REFERENCES}

Aspizain, C. (2014). The Effect Of Service Quality Of Corporate Rebranding On Brand Image, Customer Satisfication, Brand Equity, and Costomer Loyalty. Russian Journal of Agricultural and SocioEconomic, 6(3), 120-132. https://cyberleninka.ru/article/n/the-effects-of-service-quality-andcorporate-rebranding-on-brand-image-customer-satisfaction-brand-equity-and-customerloyalty-study-in.

Ayuni, Q., Cangara, H., \& Arianto, A. (2019). The Influence of Digital Media Use on Sales Level of Culinary Package Product Among Female Entrepreneur. Jurnal Penelitian Komunikasi Dan Opini Publik, 23(2). https://doi.org/10.33299/jpkop.23.2.2382.

Chrisandi, N. P. (2014). Hubungan Citra Merek dan Kualitas Pelanggan dengan Loyalitas Pelanggan Produk Apple. Calyptra, 3(1), 1-11. http://webhosting.ubaya.ac.id/ journalubayaac/index.php/jimus/article/view/1515.

Dasuki, H. (2017). Pengaruh Corporate Rebranding Terhadap Loyalitas Konsumen PT. EIGER Melalui Brand Association dan Reputasi Perusahaan (Studi pada UKM Pencinta Alam di Bandar Lampung) [Universitas Negeri Lampung]. http://digilib.unila.ac.id/28228/.

Hardilawati, W. laura. (2020). Strategi Bertahan UMKM di Tengah Pandemi Covid-19. Jurnal Akuntansi Dan Ekonomika, 10(1), 89-98. https://doi.org/10.37859/jae.v10i1.1934.

Hidayat, D. R., \& Firdaus, M. R. (2014). Analisis Pengaruh Kualitas Layanan, Harga, Kepercayaan, Citra Perusahaan, Dan Kepuasan Pelanggan Terhadap Loyalitas Pelanggan (Studi Pada Pelanggan Telkom Speedy Di Palangka Raya). JWM: Jurnal Wawasan Manajemen, 2(3), 237-250. https://doi.org/10.20527/jwm.v2i3.16.

Khan, M., Rasheed, S., Islam, F., Ahmed, H., \& Rizwan, M. (2016). Corporate branding, emotional attachment and brand loyalty: The case of luxury fashion branding. Journal of Fashion Marketing and Management, 17(4), 403-423. https://doi.org/10.1108/JFMM-03-2013-0032.

Kotler, P., Kartajaya, H., \& Setiawan, I. (2017). Marketing 4.0 Moving from Tradisional to Digital. Wiley.

Kurniawan, D. A. (2016). Pengaruh Persepsi Harga, Kualitas Pelayanan dan Citra Terhadap Niat Konsumen untuk Word of Mouth dengan Kepuasan sebagai Variabel Mediasi (Survei pada BPJS di Kabupaten Ponorogo). Al Tijarah, 2(1), 94-118. https://doi.org/10.21111/tijarah.v2i1.665. 
Moleong, L. J. (2004). Metodelogi Penelitian. Remaja Rosdakarya.

Muayyad, D. M., \& Gawi, A. I. O. (2017). Pengaruh Kepuasan Kerja Terhadap Produktivitas Kerja Pegawai Bank Syariah X Kantor Wilayah II. Jurnal Manajemen Dan Pemasaran Jasa, 9(1), 75-98. https://doi.org/10.25105/jmpj.v9i1.1396.

Pakurár, M., Haddad, H., Nagy, J., Popp, J., \& Oláh, J. (2019). The service quality dimensions that affect customer satisfaction in the Jordanian banking sector. Sustainability, 11(4), 1-24. https://doi.org/10.3390/su11041113.

Petricia, D., \& Syahputra. (2015). Pengaruh Kualitas Produk, Harga, Promosi dan Kualitas Pelayanan terhadap Proses Keputusan Pembelian (Studi pada Konsumen Kopi Progo Bandung). Eproceeding of Management, 2(2), 2117-2124.

Santosa, A. T. (2019). Pengaruh Kualitas Pelayanan, Kualitas Produk, Store Atmosphere, Dan E-Wom Terhadap Proses Keputusan Pembelian (Survei Terhadap Konsumen Zenbu-House Of Mozaru Paris Van Java, Bandung). Jurnal Manajemen Maranatha, 18(2), 148-158. https://doi.org/10.28932/jmm.v18i2.1613.

Solihin, D. (2020). Pengaruh Kepercayaan Pelanggan Dan Promosi Terhadap Keputusan Pembelian Konsumen Pada Online Shop Mikaylaku Dengan Minat Beli Sebagai Variabel Intervening. Jurnal MANDIRI: Ilmu Pengetahuan, Seni, Dan Teknologi, 4(1), 38-51. https://doi.org/10.33753/mandiri.v4i1.99.

Srisusilawati, P. (2017). Kajian Komunikasi Pemasaran Terpadu Dalam Mendorong Keputusan Pembelian Jasa Perbankan. Amwaluna: Jurnal Ekonomi Dan Keuangan Syariah, 1(1), 1-18. https://doi.org/10.29313/amwaluna.v1i1.1993.

Sugiyono. (2018). Metode Peneiltian Kuantitatif, Kualitatif dan R\&D. In Alfabeta Bandung.

Sumiati, S., \& Mujanah, S. (2018). Persepsi Kualitas Produk, Persepsi Harga dan Promosi Terhadap Keputusan Pembelian Tas Sophie Paris pada Mahasiswa. AMAR (Andalas Management Review), 2(2), 1-10. https://doi.org/10.25077/amar.2.2.1-10.2018.

Supariyani, \& Hesty, E. (2014). Pengaruh Personal Selling Dan Promosi Penjualan Terhadap Keputusan Pembelian pada PT. Yakult Indonesia Persada. Sekolah Tinggi Ilmu Ekonomi Kesatuan. Indonesia. https://www.researchgate.net/profile/Emmy_Supariyani/publication/331565143_.pdf.

Thomas, J. F. (2016). Analisa Pengaruh Rebranding Terhadap Brand Association Dengan Brand Image Sebagai Variabel Intervening Terhadap Customer Loyalty Pada PT Telkom Indihome Surabaya. Jurnal Strategi Pemasaran, 3(2), 1-10. http://publication.petra.ac.id/index.php/manajemenpemasaran/article/view/4438.

Untari, D., \& Fajariana, D. E. (2018). Strategi Pemasaran Melalui Media Sosial Instagram (Studi Deskriptif Pada Akun @Subur_Batik). Widya Cipta -Jurnal Sekretari Dan Manajemen, 2(2), 271-278.

Wijayanto, I. (2013). Pengaruh Citra Merek Terhadap Loyalitas Konsumen. Jurnal Ilmu Manajemen (JIM), 1(3), 910-918. https://jurnalmahasiswa.unesa.ac.id/index.php/jim/article/view/4557.

Winata, D. H., \& Andjarwati, A. L. (2018). Pengaruh Rebranding Terhadap Loyalitas Dengan Citra Merek Sebagai Variabel Mediasi (Studi Pada Po Sugeng Rahayu). Jurnal Ilmu Manajemen (JIM), 7(2), 327333. https://jurnalmahasiswa.unesa.ac.id/index.php/jim/article/view/26105.

Wiranata, A., \& Yuldinawati, L. (2014). Pengaruh Rebranding Terhadap Loyalitas Konsumen (Studi Kasus Fourspeed Nomad Di Kota Bandung 2014). Proceedings of Management, 10(1).

Wood, M. B. (2009). Perencanaan Pemasaran (B. Monel (ed.); 3rd ed.). PT Indeks. 